\title{
Aleksander Wat and His Polish-Jewish Identity: The Dilemmas of Identity of the 20th Century Polish Writers of Jewish Background
}

\author{
Bogusław Gryszkiewicz \\ Institute of Polish Philology, Pedagogical University of Krakow, Poland
}

Copyright $(2016$ by authors, all rights reserved. Authors agree that this article remains permanently open access under the terms of the Creative Commons Attribution License 4.0 International License

\begin{abstract}
The present study aims to bring to light the problem of the ethnic identification of Aleksander Wat, an outstanding Polish-Jewish poet. Debating common view of Jew and Pole being synonymous in Wat's ethnicity, the author attempts to trace the development and the transformation of this ethnicity. The author shows the dynamics of its evolution in a theoretical framework in the form of a fluid and dynamic model of ethnic identity. Focusing on the historical context is imperative in asserting that in the case of Wat his comprehension of the Holocaust initiated a process of rebuilding and consolidation of his Jewish identity (the poet's version of spiritual Aliyah). The final phase of the process can also be contributive to othering of his Polish "habitus".
\end{abstract}

Keywords Aleksander Wat, 1900-1967 Twentieth-century Polish Literature, Ethnic Identity, Jewishness, Holocaust

It would not be quite accurate to say that the current study extends previous research examining the question of ethnic identity of outstanding Polish poet Aleksander Wat. Although attention has been paid to the issue, it still exists outside of the mainstream of the Wat scholarship - mainly as an example of essentialist thinking about ethnicity. I am going to critically discuss the stereotype, according to which the poet's Polish-Jewish identity was something monolithic and stable, independent from the course of History and the changes of Wat's personal life.

In the title of my paper, I deliberately used the conventional phrase "the dilemmas of identity". I hope that this much-used tag will evoke in your minds (even if you are unacquainted with the name of Aleksander Wat), some associations with the problems usually discussed when the topic of literary and artistic activity within the Jewish Diaspora is being introduced - even if the particular artist is much more widely known then Aleksander Wat himself.
One has to stress, that this topic was for many years hardly even present in the Polish academia and literary criticism. This situation stemmed from the fact, that Polish academic interests were largely defined in a social climate shaped by literary doctrines and intellectual trends, in which the issues of "ethnicity" were hardly discussed at all. However, since we are interested in the issue of Jewish identity of a Polish writer, one has to mention the limits and constraints of the cultural politics of a communist state. These were, in themselves, indirectly connected to the relics of Polish national xenophobia, racism and anti-Semitism. The thing is, that an "excessive" and overt interest in the Jewishness of a particular author was perceived by the literary scholars either as a declaration of one's own ethnic origins, or (the other way around) as a pitiful proof of one's anti-Semitic phobia. To make this seeming contradiction clear, one has to remind that the Jewish identity of numerous Polish writers especially immediately before World War II - was an inflammatory issue for the nationalistic critics, who overtly tried to remove Polish-Jewish writers from the Polish literary scene.

It seems bitterly ironic, that before 1939 in Poland a large body of Jewish literature experts emerges and the scholarly methods are being improved - but the terms of the discussion itself are as sharp and violent as a razor blade of anti-Semitic hooligans. The discussion is often accompanied by true, however perverse, passion towards the subject - but even this passion remains at all times at the service of an intellectual project of making a world servile to the ideology; of winning a cultural war of one's own making. Let us use one example: in 1933 one of the overtly anti-Semitic periodicals published a list of contemporary Polish-Jewish writers and submitted the following commentary:

The Jews writing currently in Polish may be divided into the following categories:

1. Those with apparent goal to acquire steady position within Polish literature

2. Those to whom this goal is not entirely foreign, and 
who write in Polish for Jewish readers of Jewish periodicals

3. Those who we may call "the mixed type",i

Eugenia Prokop-Janiec has astutely noted, that this very commentary - however aggressive and spiteful in itself indicated how aware the nationalistic fraction was of the variety of notions of ethnic identity among the Polish Jews. What's more, they knew how big a role Polish-Jewish press played in the development of Polish-Jewish writers in this community. Nevertheless, it seems proper to think, that the basic function of the aforementioned "classification" was not so much to properly characterize three groups of Polish-Jewish writers (however this goal was achieved), as rather to stress - within a discourse of racist difference - that those writers are alien to Polish culture.

It is a clear indicator of how strongly perpetuated the anti-Semitic stereotypes were, that there were so few scholars and critics of Jewish descent, who tried to cope with the subject themselves. Their freedom of discussing it was limited by fear that they might have been accused of wanting to "fight back" to themselves what has already been incorporated into Polish literary canon, into the national culture, and in some paradoxical cases - into the nationalistic tradition itself. Within that context, it was Artur Sandauer, who held an absolutely unique position - for many years (partly because the competition was so little), he monopolized the field of literary criticism that for many others remained taboo: the works of assimilated writers. One of his achievements was to consequently return to these matters, often in an overtly autobiographical manner, expressing on various occasions his thoughts on "the situation of a Polish writer of Jewish descent in the $20^{\text {th }}$ century". In spite of his vast knowledge and extraordinary intelligence, however, he was a guide that the intellectually incisive parts of his public found hard to trust. He revolted many by harshness of his opinions, which were all too often based on his personal sympathies (and - even more often antipathies), and which in some cases included political motives - a strategy he himself accused his adversaries of, and willingly. It is characteristic of him, that his standoffishness many a time was unpleasantly directed against some of the writers of the Jewish descent.

Since the early Eighties, when all that was available to a Polish reader interested in the subject were Sandauer's essays and (printed unofficially) notable Aleksander Hertz's book Jews in the Polish Culture, there have been some major changes. Most of them are positive. A Polish reader could get to know not only the work of older authors (most of them writing in between two world wars), but also of the contemporary ones, namely Ida Fink, Stanisław Benski, Bogdan Wojdowski, Henryk Grynberg, Julian Stryjkowski, Stanisław Wygodzki, Leo Lipski, Hanna Krall, and aforementioned Artur Sandauer. It is even hard to count all the books and essays devoted to the writers preoccupied with Jewish themes, revealing along the way their own participation in Jewish history and culture. It has to be mentioned, however, that a large portion of these works was devoted either to the experience of the Holocaust, or dealt with matters disconnected in a direct fashion from Jewish themes, and - therefore - Jewish identity itself.

As I tried to show, a contemporary reader can learn quite a lot about Polish writers of Jewish descent. Thanks to removal of the institution of censorship and the radical weakening of the personal censorship of the authors (which I perceive as a direct consequence of rampant pre-1939 anti-Semitism), an important goal has been achieved. It is now possible to talk in clear and open terms about the Jewishness of the authors unmistakably crucial to Polish culture, whose work is a solid source of national pride.

Even though the number of scholarly works on Polish writers of Jewish descent is constantly growing, there is still quite few among them that tackle the subject of the authors' Jewish or Polish-Jewish identity. Until now, I tried to point out the causes of this situation in the cultural, as well as psychological context, but one has to consider also the specific limitation of scientific research. The problems of ethnic identity itself are immensely subtle and complex, and they become even more complex when the identity is regarded in the context of the twentieth century Jewish Diaspora. The proofs of this complicated status are numerous: vast number of scholarly work on the subject, many popular takes on it, autobiographical prose (like Alain Finkielkraut's famous Le Juif imaginaire), and fiction, with the most obvious representative in Philip Roth's obsessive dealings with self-definition.

The rise of interest in these matters in the Jewish world, which we can observe in recent years, has to be connected to increasing diversity in the definitions of who is a Jew, but the controversial issue of Jewish identity is much older than that. It derived from the specific life conditions within the Diaspora: the constant menace of anti-Semitism, persecution, genocide, the processes of acculturation and assimilation. According to David Theo Goldberg, the Jews as a group: “(...) raise in an especially acute way the general question of what it means to have an identity, to identify with a culture, and to be identified in terms of cultural membership"[Qtd. in: Wilentz, p. 69].

What's more, Harriet Hartman and Debra Kaufman write about the limitations and opportunities connected to constructing a definition of Jewishness:

Trying to categorize Jewish identity as religious or ethnic, assimilationist or distinctive, communal or privatize, poses theoretical and measurement problems. Indeed, Jewish identity seems best captured by the dialectics call for a fluid and dynamic model of identity, one capable of recognizing the different "journeys" over the life course and different socio-economic settings for its many expressions. [Hartman, \& Kaufman, p. 385]

It is indeed so: due to a merging of ethnic, religious and cultural aspects within Jewish identity, the best model to describe it is a dynamic one, which represents the 
free-flowing and individual phenomenon, that changes over time [See: Hartman, \& Kaufman, p. 372]. What's more, it remains in a dialogic relationship to history and to the conditions of a specific contemporary situation. It's a model of identity which can transform itself, intensify itself, lose power, appear and disguise itself. It's a polar opposite of a permanent, irreducible and monolithic model characteristic of an essentialists' approach.

There is no contradiction between this free-flowing model and the model of Jewish identity argued by Michael Krausz. We owe him a very useful distinction between the "identity by descent" and the "identity by assent" [See: Schostak, p. 740]. In the case of the former, what's at stake is the traditional model of identity, based on rabbinical laws: "One is Jewish by assent (...) if one identifies with and positions oneself in Jewish historical narratives" [Qtd. in: Schostak, pp. 740-741]. Krausz is convinced that: “(...) there is no essence of the Jewish people as such. Rather, there are people in Jewish positions, or positions that are bestowed as Jewish. Jewishness is understood as a set of characteristic positions in which certain people are cast or ascribed-by themselves and by others" [Qtd. in: Schostak, p. 744].

Krausz's definition of Jewishness includes not only a specific choice to be made within the symbolic space, but also an act of affiliation with real people and their immediate experience. In other words, to quote Leonard Fein: “(...) one is Jewish because one is Jewish, and because being Jewish is a way of connecting with a past and with other Jews in the present" [Qtd. in: Kaufman, p. 162]. This "connection" is most fully captured and expressed by the term "solidarity", which - according to a definition put forward by David A. Hollinger - may be seen as " (...) an experience of willed affiliation” [Hollinger, p.24]: “(...) To share an identity with other people is to feel solidarity with them: we owe them something special, and we believe we can count on them in ways that we cannot count on the rest of the population" [Hollinger, p. 23].

In the context of conventional notions popular not only inside the Jewish community itself, this - one might say "proverbial" solidarity becomes an important element of the group identity: "Jewish solidarity - according to Lisa Moses Leff - has become so integral to Jewish identity that it is usually assumed to be a natural, unchanging part of what it means to be Jewish" [Leff, p.33].

And when twentieth century Jewish solidarity is mentioned, one cannot avoid pointing at the state of Israel as its foundation for at least a part of the Diaspora. Let us add also for the hero of this paper. The hero who himself is a twentieth century's peer: Aleksander Eliasz Wat, the author of acclaimed - but also considered difficult - poetry; of prose, memoirs and diaries; Sovietologist, critic of literature and the arts, much-cited in Poland and elsewhere. Born on 1 May 1900 , in Warsaw, in a family of rabbinical traditions, up till 1915 he attended Russian schools, and then - classical gymnasium. Between the world wars he studied philosophy in Warsaw for a couple of years, simultaneously taking part in a Polish avant-garde movement one may call futuro-dadaistic. In 1919 his literary début was published: $J A$ z jednej i JA z drugiej strony mego mopsożelaznego piecyka [ME from One Side and ME from the Other Side of My Pug Iron Stove], long prose poem which was an experiment in automatic writing - conducted several years before André Breton introduced the term écriture automatique. In 1926 he published a collection of philosophical novellas and tales Bezrobotny Lucyfer [Lucifer Unemployed], which became a literary success that transformed Wat into a much talked-about writer. In 1927 he married a daughter of a wealthy Jewish family, Paulina (Ola) Wat. At the late 1920s he began to sympathize with the Communist Party. Between 1928 and 1931 (without becoming a member of Polish Communist Party [KPP]) he edited the Party's literary organ Miesięcznik Literacki [The Literary Monthly]. Since 1933, up till 1939, he was a literary director in Gebethner \& Wolff Publishing House, and participated actively in the proceedings of The Professional Association of Polish Writers, and the Polish branch of International PEN. After the war broke out, he managed to move (along with his wife and son) to Russian-occupied Lvov, where he briefly contributed to Czerwony Sztandar [The Red Banner], a Soviet newspaper printed in Polish. As a consequence of the so-called "Lvov provocation" he was arrested on 24 January 1940. He was held in a few Soviet prisons, and released after the so-called "Sikorski-Majski Pact" in November 1941, and began to work for the delegation of the Polish government-in-exile in Alma-Ata. Since February 1943 he stayed with his family in Ili, near Alma-Ata. It was there, where as an organizer of the resistance towards so-called pasportization (forcing Polish deportees in Kazakhstan to accept Soviet passports), he was once again arrested. He returned to Poland in the April of 1946 . He was still an active member of International PEN and The Professional Association of Polish Writers; he was the head of a major national publishing house, as well. After the forced introduction of the poetics of social realism to Polish literature in 1949, he ceased to publish his own work. He made his living as a translator. In 1953, along with his wife, he was secretly baptized. In 1957 Wiersze [The Poems] appeared, and were consequently recognized as "the book of the year". Since the mid-Fifties, because of his health condition, he spent vast amounts of time in the South of Europe. In 1959 he left Poland for good. In 1961 he settled in France, and then lived for some time in Berkeley, where he gave a number of interviews to Czesław Miłosz - these interviews were later edited and published as two-volume "spoken diary" Mój wiek [My Century]. These two volumes still serve as a source of knowledge about the author's life, and are also abundant with information on the left-wing literary movements in pre-1939 Poland. They serve, also, as a deep analysis of the Stalinist assault on freedom. In 1965 the Wats came back to Europe and settled in France. On 29 July 1967 the poet ended his own life. Shortly before his death, shocked by the outburst of Six-Day War, he wrote a letter to the members of Polish emigration, pleading for their solidarity with Israel. It wasn't his first statement of this kind: 
in 1948, in the context of the Arab-Jewish war, he pleaded similar case in an open letter to Paweł Hertz.

I deliberately mentioned those two open statements, because Wat's public commitment to State of Israel hasn't been yet fully acknowledged in the scholarship devoted to his life and work. It may be partly due to the fact that the issue of the poet's Polish-Jewish identity still remains outside of the mainstream of this scholarship. That is to say: the topic is brought up relatively often, but mainly as an appendix to discussion of other issues: like pain, illness, loneliness, rebellion, religious and quasi-religious experiences, embracing Communism and radical departure from totalitarian ideology. The most incisive observations on Wat's complicated identity are to be found in a lengthy study by Lithuanian author Tomas Venclova: Aleksander Wat. Life and Art of an Iconoclast ${ }^{i i}$. One has to note, however, that his generalizations on these matters do not redefine the notions established and preserved by the Polish scholars. In the chapter entitled „Prehistory, 1900-1918” Venclova argues:

Wat's Jewish identity was probably never in conflict with his Polish identity. As both Jew and Pole, he experienced himself as belonging to a humiliated, persecuted people whose opportunities to dignity and independence had been denied over and over again. He felt solidarity with both groups, and they blended in his consciousness, even at times when the tension between them was overweening [Venclova, p. 14].

This notion of a peaceful co-existence of two elements (Polish and Jewish) is close to a rhetorical figure used in a speech given at Wat's funeral (on 1 August 1967) by his friend, Józef Czapski:

(...) A Pole and a Polish poet, rooted into Poland and its tradition - both historical and poetic - rooted into its cruel fate. He was part of the Polish culture as much as it was part of him: he co-created it.

A Jew, totally immersed in Jewishness - its past and its tragedy; for him, the Bible was a book he was inseparable from, until the day he died

A Man, who discovered the revelation of Christianity in prisons and during Soviet exile; from then on the New Testament was as dear a book to him, as the Old one.

The gratitude felt by so many of us towards him, is not only personal: he was a living example of a symbiosis of two traditions - we know, how this symbiosis has deepened and widened our consciousness.

It will last well beyond us all, it will bond together Poles and Jews, whose fates were merged by the centuries lived in the same very land [See: Czapski, p. 2].

The vision of untroubled harmony between two identities that Czapski draws was motivated (at least in part) by the funeral convention, and also by the politics of the speech.
After all, it was given on 1 August 1967, and presented a perfect occasion to manifest Polish-Jewish solidarity with Israel during the Six-Day War, and to denounce international sanctions against Israel, as well as a harsh anti-Semitic campaign that was held in Poland in that time. The campaign started on 19 June with a speech by Władysław Gomułka, who described Polish citizens of Jewish descent as "the fifth column". As we can see, then, the circumstances for coining the formula of "peaceful co-existence" were specific and belonged to a particular historical moment - however, they formed a powerful pattern that is perpetuated in the critical discourse concerned with the author of My Century - and Venclova's work is the most obvious example here. Wat himself perpetuated this pattern, by confessing in his Moralia (a diary kept in the 1950s), what follows:

I never felt myself either a Polish Jew or a Jewish Pole (...) I always felt myself a Jew-Jew and a Pole-Pole (as they would say in French). It is difficult to explain, yet it is true. I have always been proud (if one is permitted at all to be proud of belonging to this or that group) that I am a Pole, that I am a Jew. And simultaneously driven to despair that I am a Pole, that I am a Jew. What a lot of bad luck! [Qtd. in: Venclova, pp. 14-15]

It is this passage that Venclova and others quote when they discuss the poet's Polish-Jewish identity, but they fail to add, that this self-definition stands in visible contrast to some statements made by Wat in his later years. Anna Micińska boldly states that "Wat never had any problem with defining his identity" [Micińska, pp. 13-14]. This recklessly used "never" (Wat was equally reckless in using it) is the best indicator of a failure to evaluate the autobiographical material of A Diary without Vowels and My Century, but also of large portions of Wat's fiction. "Never", which is to say: in no time, in no place, in no situation whatsoever... But the relative ease of self-definition belongs only to two specific stages of Wat's life: the flirt with Communism and the last years spent on emigration. These were the periods of a powerful autobiographical focus, accompanied and enforced by the effort to form a distinctive Jewish identity, which later became the central identity of the autobiographical "I". Making his Jewish identity integral was all the more powerful a process after the war, in the painful confrontation with the truth about Holocaus ${ }^{\mathrm{iii}}$, about the tragedy of those dear to Wat. This process consists of gradually defining Wat's "otherness", "separateness": of being Jew-Jew. There is no reason to assume that the self-assurance about his identity showed in the 1950s was with him at all times - after all, he does mention his own anti-Semitism of his youth. There is no doubt, however, that this identity played a crucial role in the last phase of his life; everything that counts as a valid biographical source testifies to that. And in this I include his poems, which were by no mistake called by Czesław Miłosz "unashamedly autobiographical" [Miłosz, p. $50]$. The Jewish identity of the mature poet is represented in these sources as something complete and integral - 
something being affirmed, monumentalized even. In other words: something constructed in a very different manner than this observed in so-called assimilated writers and in Wat himself in the earlier stages of his career. Due to the time constraints I can only name the things I personally consider as the most important or the most characteristic of this construction.

For one thing, there is the way Wat reminds us of the genealogy of his family, over and over again. It is almost compulsive in its manner: we find it in My Century, parts of The Diary, in letters, poems: "I am a distant descendant of the $11^{\text {th }}$ century philosopher of Troyes, Rashi, the commentator of the Bible, the son of generations of rabbis, of the high-priest line" [Wat, p. 249]. There are also frequent reminiscences of his childhood, spent in a Jewish home, which champion the father: an orthodox Jew, and at the same time a man of great tolerance and fondness towards the secular culture. There are the memories of humiliations, experienced by the young poet in contact with the un-Jewish world in childhood and youth. But there is, also, a distinctive reluctance towards discussing his own work, which - like The Stove... - themselves were the proof of the deep crisis of Jewish identity (and therefore became a poignant illustration of a phenomenon described by Sander L. Gilman as "the Jewish self-hatred"). Other works - like The Jew, the Eternal Wanderer - showed the swaggering attitudes of a young, left-wing dandy, towards his own Jewish childhood. In this revision of themes, one has to point out also the complicated structures of reasoning and of artistic approach that Wat (the diarist, the poet) employed to reconcile his sense of being Jewish with his later apostasy (his deep fascination with Christianity was born in the Soviet prisons). It is here where the hypothesis of Alina Kochańczyk seems really useful: she claims that the real undercurrent of Wat's work is a complex of guilt towards the world which he willingly rejected in his youth. Kochańczyk's argument would be much more convincing if the Freudian apparatus she employs was replaced by reflection on guilt itself - which doesn't necessarily stem from masochism. It rather seems to be the natural consequence of a shock for one "saved in the East", who began to realize that the world of his childhood simply does not exist anymore. The testimony of this shock is to be found in Wat's deeply moving poems about the Holocaust, and in his passionate voice calling for international attention to "an endangered Israel". The traces of this shock are also visible in his poems that disguise as footnotes to the Old Testament, as well as in the work in which the hero identifies himself with characters that personify pain and suffering: namely Job and Jesus.

Contrary to the Jewish identity, which in Wat's late work is presented as full and impossible to destroy - the representations of the Polish identity are permanently connected to the feeling of uncertainty and lack. The cause of this is to be found in the poet's outsider status among the members of Polish war emigration - which still held strongly ingrained anti-Semitic ideas and stereotypes. The words he uses to describe a holiday visit in a traditional Polish household are especially telling:

The undercurrent of anti-Semitism, even though no one sang Christmas carols, and those played on the gramophone were Brazilian ones. Horror. A lady: "Why, but his parents aren't Jewish, are they...?!" she said this about a young engineer K..., who doesn't speak a word of Polish.

Why did we come here, after all? (...) A true warning sign: stay away from the "society" and problems stay away from the Polish world. Ultimately, we ended up at the very same backyard Tuwim did. Back then, busy with building solidarity with the beaten Polish society, I didn't understand his phobia. But here: stay away from Poland. I am and always have been a cosmopolitan Jew who spoke Polish, that's all [Wat, p. 166].

This last sentence is the beaming opposite of the 10 -years-older self-definition, which - as we have seen was quoted as a "proof" of a lasting symbiosis of two identities. Let us try to remove the phrase "and always have been", and we will get an answer to a question, what kind of changes occurred in Wat's way of thinking about his connections toward Polishness. There are numerous opinions that he gave towards the end of his life on the subject of the Polish people, the Polishness itself - even this kind of Polishness that he once felt (and celebrated) as his own. They all confirm that the answer we got by removing this one phrase, is valid.

The critics who wrote about Polish-Jewish identity of Aleksander Wat seem unable to free themselves from the intellectual stereotype, according to which ethnic identity is something static and monolithic, independent from the ever-changing conditions of a person's life. This same train of thought can be seen both in the writings of those, who argue Wat's Polish identity to be undefeatable, and in the writings of Alina Kochańczyk, who argues something opposite: "The Diary without Vowels clearly indicates that Wat never considered himself a Pole. Even when he showed the courage that elevated himself in his own eyes, when he defended his Polish citizenship, what he in fact did, was to stand up against the brutal sovietisation" [Kochańczyk, pp. 97-98]. Here comes this suspicious „never”, again - a clear indicator of the unwillingness to admit that the notion of one's ethnic or national identity can change overtime - and especially in the characteristic environment of Diaspora. It makes one wonder all the more, if one takes into account what's visible in Wat's autobiographical writings, his letters and poems, is the process of undoing his ties with Poland. This undoing is very similar to so many well-known "escapes"/"returns" from and back to Polish culture, which are characteristic of the 1930s: the rampant anti-Semitism made many assimilated writers to go reclaim their original ethnic positions and rebuilt their lost ethnic capital. This phenomenon was also reflected in literature, and Lato [The Summer] by Adolf Rudnicki makes for a perfect example. If one was to prepare an anthology of these works, which 
expressed all the grief and bitterness, one would definitely have to include in it some of the late works of Aleksander Wat. Consider especially the following, written on 9 June 1967, shortly before the poet committed suicide:

On Good Friday, when the bells are already ringing midnight,

I withdraw from the altar. I leave the community of the faithful,

their sweet converse with the saints is not for me.

They'll start to seek me

Already on Holy Saturday and Happy Easter, and then

On the Last Thursday of the Carnival

- with knives - among these, whom the nice old lady (she who added brushwood to the pyre of Hus) saw pricking the Holy Host.

I would like to return barefoot, on the sharp rocks, to the Wailing Wall.

My place is there. I shall not withdraw from it.

Perhaps I would just run off to the road to Emmaus. If I only could put my numb fingers

into the wounds of Man. These truly do not heal. Ever.

The rest is silence. [Qtd. in: Venclova, p. 306]

This openly autobiographical poem could be read as an attempt at a personal mythology, by which the author fosters his self-assertion as a Jew: an apostate, sufferer and a subject of spiritual Aliyah - the journey which I attempted to trace in this paper.

Translated by Michat Oleszczyk

\section{REFERENCES}

[1] Czapski, J. (1967). Wiadomości (London) No 1118 (3th September).

[2] Gilman S.L., (1986). Jewish Self-Hatred. Anti-Semitism and the Hidden Language of the Jews. Baltimore and London: The Johns Hopkins University Press.

[3] Hartman, H., \&Kaufman, D. (2006). Decentering the Study of Jewish Identity: Opening the Dialogue with Other Religious Group. Sociology of Religion 67 (4), pp. 365-385.

[4] Hollinger, D.A. (2006). From Identity to Solidarity. Daedalus 135 (4), pp. 23-31.

[5] Kaufman, S. (1998). Roots in the Air (A Poet Grapples with Jewish Identity through Art and Literature) . Judaism 47(4), pp. 161-168.

[6] Kochańczyk, A. (1992). „Dziennik bez samogłosek” Aleksandra Wata studium do autoportretu. In: Wyskiel, W., Pamięć głosów. O twórczości Aleksandra Wata. Studia. Kraków: Towarzystwo Autorów i Wydawców Prac Naukowych "Universitas", pp. 5-101.

[7] Leff, L.M. (2002) Jewish Solidarity in Nineteenth-Century France: The Evolution of a Concept. The Journal of Modern History 74(1), pp. 33-61.

[8] Micińska, A. (1992). Aleksander Wat - elementy do portretu. In Wat, A., Poezje zebrane. Opr. Micińska, A., \& Zieliński J. Kraków: „Znak”. pp. 5-109.

[9] Miłosz, Cz. (1990). O wierszach Aleksandra Wata. In Miłosz, Cz. Prywatne obowiazki. Olsztyn: Pojezierze, pp. 49-58.

[10] Prokop-Janiec E. (1992). Międzywojenna literatura polsko-żydowska jako zjawisko kulturowe $i$ artystyczne, Kraków: (English translation: Polish-Jewish Literature in the Interwar Years, Syracuse University Press 2003)

[11] Shostak, D. (1997). The Diaspora Jew and the "Instinct for Impersonation": Philip Roth's Operation Shylock. Contemporary Literature 38 (4), pp. 726-754.

[12] Venclova, T. (1996). Aleksander Wat. Life and Art of Iconoclast. New Haven: Yale University Press.

[13] Wat., A. (2001). Dziennik bez samogłosek. Wydanie zmienione opracowali oraz przypisami i indeksem opatrzyli Krystyna i Piotr Pietrychowie. Warszawa: Czytelnik.

[14] Wilentz, G. (2001). Healing the "Sick Jewish Soul": Psychoanalytic Discourse in Jo Sinclair (Ruth Seid)'s Wasteland. Literature and Psychology, 47(1-2), pp. 68-93.

\footnotetext{
¿̇ydzi w literaturze, „Gazeta Warszawska” 1933, no 275. Quoted in: E. Prokop-Janiec, p. 102.

ii Polish translation by Jan Goślicki: Aleksander Wat. Obrazoburca, Kraków 1997.

iii Sander Gilman rightly says that „The Holocaust has been the most momentous force to shape modern Jewish identity. Its force was felt not only among those Jews who directly experienced it but among all individuals who could even remotely perceive themselves as a Jews" [S.L. Gilman, p. 319].
} 